\title{
Impact of life course determinants on work participation among young Norwegian men
}

\author{
Petter Kristensen, ${ }^{1,2}$ Tor Bjerkedal, ${ }^{2,3}$ Lorentz M. Irgens, ${ }^{4}$ Hans Magne Gravseth ${ }^{1}$ \\ and John Ivar Brevik ${ }^{3}$ \\ 1) National Institute of Occupational Health, Oslo \\ 2) Section for Preventive Medicine and Epidemiology, Institute of General Practice and Community Medicine, \\ University of Oslo, Oslo \\ 3) Division of Military Medical Research and Development, Joint Norwegian Medical Services, Oslo \\ 4) Medical Birth Registry of Norway, Locus of Registry Based Epidemiology, University of Bergen, Bergen, \\ and Norwegian Institute of Public Health, Oslo \\ Correspondence: Petter Kristensen, National Institute of Occupational Health, P.O. Box 8149 Dep, 0033 Oslo, Norway \\ Telephone: (+47) 23195373 Telefax (+47) $23195200 \quad$ e-mail: petter.kristensen@stami.no
}

\begin{abstract}
SUMMARY
Background: We have earlier found that birthweight below the mean, parental factors, and childhood disease were associated with unemployment at age 29 . We reanalysed data because we wanted to examine if the association between birthweight and subsequent unemployment was mediated by intellectual performance at conscript.

Methods: Through linkage between several national registers, containing personal information from birth into adult age, we established a longitudinal, population-based cohort. Study participants were all 158026 male singletons born in Norway in 1967-1971 as registered by the Medical Birth Registry of Norway who were national residents at age 29. Study outcome was unemployment defined as a lack of personal income among persons who were not under education in the calendar year of their $29^{\text {th }}$ birthday. We computed unemployment risk in separate strata, and adjusted risk ratios and population attributable risks as measures of association and impact, respectively.

Results: The association between birthweight and unemployment found earlier was mainly mediated through intellectual performance at conscript, in accordance with the study hypothesis. Birthweight, childhood disease and seven parental factors relating to income, disability, and family pattern, were independently associated with subsequent unemployment, each with population attributable risks ranging from $2 \%$ to $12 \%$. Intellectual performance in young adult age, educational attainment, and marital status contributed substantially to the unemployment risk.

Conclusion: Differentials in work participation among young men emerge in childhood. Circumstances throughout the life course contribute to the unemployment risk.
\end{abstract}

\section{NORSK SAMMENDRAG}

Introduksjon: Vi har tidligere funnet at fødselsvekt under gjennomsnittet, vanskelige oppvekstforhold og kronisk sykdom i barnealder er assosiert med mangel på arbeidsdeltakelse blant 29-årige menn. Datagrunnlaget og analysen ble utvidet for å analysere om evnenivå ved sesjon medierer assosiasjonen mellom fødselsvekt og senere arbeidsdeltakelse.

Metode: En kohort ble basert på alle levendefødte i Medisinsk fødselsregister i 1967-71. Ved hjelp av registerkoblinger fikk vi tilgang til løpende individdata på helseforhold og sosiale vilkår i livsløpet. Deltakere var alle 158026 menn fra enkeltfødsler som bodde i riket i det året de fylte 29. Studieutfall var manglende arbeidsdeltakelse definert som manglende inntekt hos menn som ikke var under utdannelse det året de fylte 29 . Vi beregnet risiko for manglende arbeidsdeltakelse i ulike strata, og relativ risiko og attribuerbar populasjonsrisiko som mål på assosiasjon og betydning av ulike risikofaktorer.

Resultater: Assosiasjonen mellom fødselsvekt under gjennomsnittet og manglende arbeidsdeltakelse ble vesentlig mediert gjennom allment evnenivå ved sesjon, i tråd med studiehypotesen. Attribuerbar populasjonsrisiko for manglende arbeidsdeltakelse av fødselsvekt, kronisk sykdom i tidlig barnealder og syv ulike sosiale oppvekstfaktorer knyttet til foreldres inntekt, uførhet og familierelasjoner, var hver i størrelsesorden $2 \%$ til $12 \%$. Evnenivå, utdanningsnivå og sivilstatus ved alder 28 år bidro vesentlig som forklaringsfaktorer for manglende arbeidsdeltakelse.

Konklusjon: Gradientene i arbeidsdeltakelse blant unge menn har sin opprinnelse i tidlig oppvekst, og forhold opp gjennom livsløpet bidrar til denne risikoen.

Key words: Adult; Birthweight; Child; Cohort Studies; Education; Employment; Follow-Up Studies; Intellectual Performance; Social Environment 


\section{INTRODUCTION}

In a cohort based on register linkage, we have shown that birthweight below the mean, early social disadvantage, and childhood disease were associated with unemployment at age 29 years (1). One speculative interpretation of the birthweight results was that birthweight could be an indicator of early development of the central nervous system, which in turn could be responsible for effect on work participation. We presented no data to support this, but the interpretation has some indirect support: there is a well-documented relation between birthweight and cognitive performance in adulthood (2-8) as well as in childhood (9-16). The effect of birthweight is not limited to low or very low weights but extends well into the normal range (2-6,913). There is also evidence that cognitive function affects educational achievements $(2,3,8,15,16)$ and adult social class (17).

We had, in addition, conscript data on intellectual test results for the men in the cohort that provided an opportunity to extend the earlier (1) analysis. Presently, we have examined the 158026 men on the relations between birthweight, intellectual performance at conscript, and work participation at age 29. Our hypothesis was that a main part of the birthweight effect on work participation would be mediated through intellectual performance. We had further objectives in the analysis. First, we wanted to extend the analysis by including additional factors during the life-course in a hierarchical modelling. Second, the indicator of social disadvantage in the earlier analysis was a composite of several parental characteristics, which we aimed at separating. Third, the logistic regression odds ratio estimations in the earlier paper tended to produce results that were not good approximations of relative risks. We therefore used regression models providing risk ratios and risk differences as association measures in the present analysis. Finally, we wanted to extend and refine the analysis of interaction between birthweight, early social disadvantage, and childhood disease on subsequent work participation.

\section{METHODS}

\section{Participants, linking procedures}

The Medical Birth Registry of Norway comprises all births in Norway with more than 16 completed weeks of gestation (18). The population base included all 170 678 live born boys, 1967-1971. The national identification numbers for the child and the parents allow linkage with other national registers. We linked the records with benefit and income registers in the National Insurance Administration, the education register in Statistics Norway, the Norwegian Armed Forces Personnel Data Base, and the Central Population Register. A total of 161808 of the men were national residents on January $1^{\text {st }}$ in the year of their 29th birthday. As in the earlier analysis (1), we excluded multiple births
$(1.8 \%)$, men with missing birthweight data $(0.2 \%)$ and men who died or emigrated during the following year $(0.5 \%)$. A total of 158026 index men were left for analysis.

\section{Study outcome}

The outcome variable was lack of income among persons who were not under education in the calendar year of their 29th birthday, which we termed unemployment. Income is reported annually to the National Insurance Administration and is recorded in units that are adjusted regularly in accordance with changes in the general income level. An income below the limit entitling to sickness absence compensation was defined as no income. Annually in October, ongoing education is recorded in the education register. We considered persons who were under education in October in the calendar year of their 28th or 29th birthday to be under education, others were not under education.

\section{Early determinants}

Linkage provided longitudinal data for the index men and their parents. Annual updates were performed through the year 2000 on education, insurance administration benefits, pensionable income, and marital status.

The early social disadvantage variable in the earlier report (1) was based on a number of parental factors relating to father's identity, parental survival, income level, disability benefits, and family pattern in different periods throughout childhood and adolescence (age 0-24 years). We kept seven parental factors that were associated with a $20 \%$ or higher adjusted increase in unemployment risk. These factors were relating to father's identity, two factors relating to parents' marital and family status, mother and father's disability, and mother and father's income level.

Father's identity was based on data in the medical birth record. Maternal and paternal disability was dichotomised depending on either parent receiving disability pension or not before age 25 of the index person. Marital status of the mother at the index boy's birth and in 1985 was dichotomised (married in both years, other). We examined whether the parents were recorded with the same number of children in the Central Population Register or not, which we interpreted as an indicator of parental relationship. Low maternal income was defined as mean pensionable income less than the limit entitling to sickness absence during index person age 17-24 years. Low paternal income was defined as mean income under the same limit on any of three age periods of the index person (0-6, 7-16, 17-24 years). In the interaction analysis (see Statistical analysis) we dichotomised parental indicators into a "disadvantage in parental factors" variable with a no disadvantage value if the index man had reference values for all seven parental factors, others were categorised as disadvantaged. 
We used the same two variables on childhood disease and birthweight as in the previous report (1). Childhood disease was defined as insurance benefit due to chronic disease before age 7 years, birth injury, or congenital malformation (as defined in reference 19). Birthweight in singletons (mean $3571 \mathrm{~g}$, SD 541 g) was separated into nine, six, four, or two categories according to SD departure from the mean. The nine category variable included four categories above the standardised mean. This variable was abandoned because birthweight categories above the mean had no influence on the association with unemployment and did not alter the relation between other variables (e.g., gestational age) and unemployment.

\section{Later determinants}

Early determinants could be mediated through factors later in life, so we included conscript data on intellectual performance and body mass index (BMI), educational attainment, and marital status at age 28.

The Armed Forces Personnel Data Base provided conscript data. All men who are drafted for compulsory military service are obliged to complete a test of general intellectual performance, usually at age 18 or 19. This test is highly correlated with the Wechsler Adult Intelligence Scale and is recorded as single digits from 1 (low) to 9 (high), the scores being normally distributed in the general population (20). BMI was also measured at conscript. We categorised BMI into four groups (below 18.50, 18.50-24.99, 25.00$29.99,30.00$ or more).

Educational attainment classification was based on the Norwegian standard classification of education NUS2000 (21). The most recent coding of education level in the register provided five categories: tertiary, graduate level or higher (NUS2000 level 7-8); tertiary, undergraduate level (NUS2000 level 6); upper secondary, final year or post-secondary/non-tertiary (NUS2000 levels 4-5); upper secondary, basic (NUS2000 level 3); and lower secondary or less (NUS2000 levels 0-2).

Data on marital status in the Central Population Register in December of the year of the 28th birthday served to classify the men as unmarried, married, or previously married.

\section{Statistical analysis}

We used STATA/SE 8.0 software in the analysis, computing unemployment risks at age 29. Associations between determinants and unemployment were estimated both as risk ratios (RR) and risk differences with corresponding 95\% confidence intervals in Poisson regression (22). Poisson regression of risk data produces too wide confidence limit estimates (22), so we used the robust variance option in STATA.

We conducted multivariate modelling on hierarchical relations between factors according to their stage in the life-course (23). The analyses were performed sequentially with models formulated a priori, distinguishing between potential mediators and confounders (24-27).

The mediating role of intellectual performance was assessed by estimating the birthweight-unemployment association in models without and with intellectual performance.

We applied the hierarchical approach in four multivariate models in order to estimate effects of early determinants after controlling for potential confounders, and in order to assess the role and strength of later determinants. Model 1 included the early determinants (seven parental variables, birthweight, and childhood disease). Model 2 included intellectual performance and BMI from conscript records in addition to model 1 factors. Model 3 included model 2 factors plus educational attainment. Model 4 included, in addition, marital status at age 28 .

Other variables potentially related to unemployment were also considered in the multivariate modelling. In all models, we included year of birth, residence at age 16, maternal and paternal age at birth, birth order, and gestational age. Throughout, missing values were included in the models as separate categories.

We calculated population attributable risk (PAR). PAR is a function of the population prevalence of a factor and the strength of an association and can be interpreted as the proportional reduction in population risk that would occur in the hypothetical case that all experience the risk of the reference category (28). PARs for individual factors and groups of factors were calculated in the AFLOGIT procedure in STATA after including the factor(s) in the regression model as dichotomous variable(s). All values except for the reference value were collapsed into one category after excluding missing values on the factor. This provided adjusted PAR estimates with 95\% CIs in the regression models. The mediating role of intellectual performance on the birthweight-unemployment association was estimated by comparing birthweight PARs in models with and without intellectual performance. We interpreted early determinant PARs in model 1 as measures of the impact of those factors on unemployment. The degree to which early determinant PARs changed in the subsequent models were interpreted as a measure of the mediating strength of factors introduced in those subsequent models.

To investigate interaction between birthweight, disadvantage in parental factors, and childhood disease we dichotomised the three factors and constructed a combined variable in eight categories whether the three had reference value or not. We defined interaction as departure from additive effect of those factors by estimating adjusted risk differences in Poisson regression. Measure of interaction (departure from additivity) was the combined risk of two or all three factors in excess (or deficit) of what would have been experienced had the combined risk been purely additive. Confidence intervals for risk in excess of additi- 
vity for combinations of two factors were calculated according to Hosmer \& Lemeshow (29) after modifications to allow for use with risk data.

\section{RESULTS}

Overall, 7255 out of the 158026 young men were unemployed (one-year risk 0.046). We calculated the intellectual performance results for four birthweight groups (figure 1). Figure 1 illustrates that the performance score was normally distributed in all birthweight groups. The distribution curves for decreasing birthweight categories were slightly but increasingly shifted to the left.

After excluding men with no data on intellectual performance ( $\mathrm{N}=11006$, unemployment risk 0.210), we found birthweight categories below the mean to be moderately associated with unemployment in an adjusted model (table 1). RR estimates in the birthweight categories were considerably closer to unity when

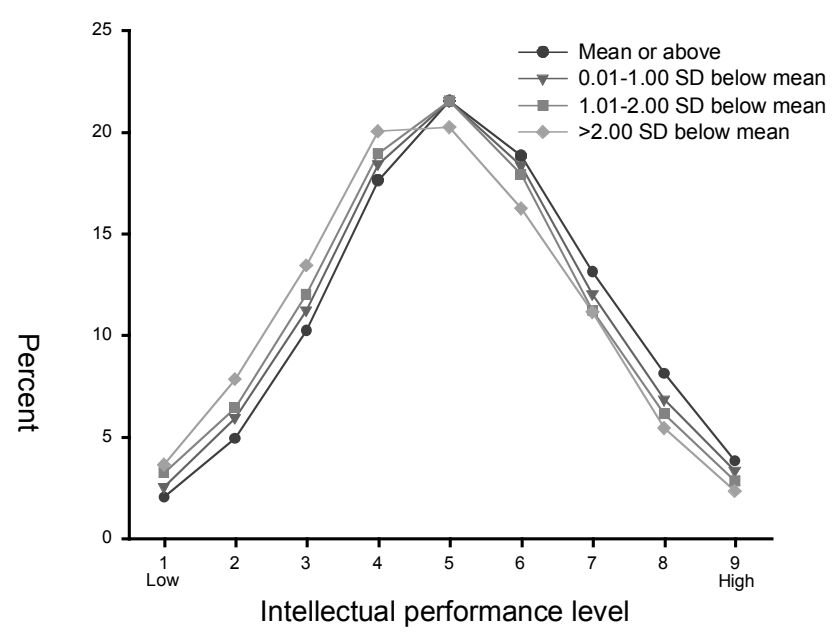

Figure 1. Distribution of intellectual performance level at conscript for men in four birthweight groups (birthweight mean $3571 \mathrm{~g}$, SD $541 \mathrm{~g}$ ). intellectual performance was added (table 1). These results were reflected in PARs of unemployment attributed to birthweight: in the adjusted model that did not include intellectual performance the PAR was $4.1 \%$ (95\% CI 1.3 to 6.8 ); when intellectual performance was added the PAR attributed to birthweight was reduced by $72 \%$ to $1.2 \%(95 \% \mathrm{CI}-1.7$ to +3.9$)$. Additional inclusion of educational attainment and marital status at age 28 had only minor additional impact on the association between birthweight and unemployment (data not shown).

Distributions of all study factors, the corresponding unemployment risks, and crude and adjusted RR estimates are provided in table 2. All the covariates considered as potential confounders of the early determinants showed moderate associations with unemployment in model 1 .

Adjusted RR estimates for the early determinants are provided in model 1 of table 2 . Both birthweight and childhood disease were associated with unemployment. Adjusted RR estimates for the seven parental factors show rather moderate associations, ranging from 1.28 (maternal disability) to 1.64 (maternal income). Among parental factors not included in the final models it is worth noting that parental death was associated with increased unemployment risk $(0.064$ when father was deceased and 0.074 when mother was deceased). The adjusted RR for father's death was below unity, however (RR $0.86,95 \%$ CI 0.78 to 0.94 ) and close to unity for mother's death (RR $0.98,95 \%$ CI 0.87 to 1.10). Parental educational level showed no association with unemployment risk level (data not shown).

Model 2 results show RR estimates for intellectual performance and BMI, adjusted for the model 1 factors (table 2). Decreasing level of intellectual performance was associated with increasing RRs. Only the lowest three levels had estimates higher than 2. The obese $(\mathrm{BMI} \geq 30)$ and underweight $(\mathrm{BMI}<18.5)$ had moderately increased risks whereas the overweight (BMI 25.00 to 29.99) had an adjusted RR of 1.00. Model 3

Table 1. The relation between birthweight and unemployment at age 29 years among Norwegian men born in 1967-1971, and the mediating role of intellectual performance at conscript.

\begin{tabular}{|c|c|c|c|c|c|c|c|c|}
\hline Birthweight category & $\mathrm{N}^{*}$ & $\%$ & $\begin{array}{c}\text { Not } \\
\text { employed }\end{array}$ & Risk & Risk ratio $\dagger$ & $(95 \% \mathrm{CI})$ & Risk ratiot & $(95 \% \mathrm{CI})$ \\
\hline$\geq$ Mean & 74816 & 50.9 & 2348 & 0.031 & 1 & (Reference) & 1 & (Reference) \\
\hline 0.01 to $1.00 \mathrm{SD}$ below mean & 52179 & 35.5 & 1788 & 0.034 & 1.06 & $(0.99-1.13)$ & 1.01 & $(0.95-1.07)$ \\
\hline 1.01 to $2.00 \mathrm{SD}$ below mean & 15996 & 10.9 & 630 & 0.039 & 1.14 & $(1.04-1.25)$ & 1.05 & $(0.96-1.15)$ \\
\hline 2.01 to $3.00 \mathrm{SD}$ below mean & 3094 & 2.1 & 141 & 0.046 & 1.31 & $(1.09-1.57)$ & 1.17 & $(0.97-1.39)$ \\
\hline 3.01 to $4.00 \mathrm{SD}$ below mean & 778 & 0.5 & 33 & 0.042 & 1.34 & $(0.93-1.93)$ & 1.19 & $(0.84-1.69)$ \\
\hline$>4.00 \mathrm{SD}$ below mean & 157 & 0.1 & 8 & 0.051 & 1.51 & $(0.74-3.11)$ & 1.16 & $(0.59-2.28)$ \\
\hline
\end{tabular}

* Excluding 11006 men with missing data on intellectual performance

$\uparrow$ Adjusted for year of birth, geographical region, maternal and paternal age, birth order, gestational age, seven parental factors, and childhood disease

\$ Adjusted for intellectual performance, year of birth, geographical region, maternal and paternal age, birth order, gestational age, seven parental factors, and childhood disease 
Table 2. Distribution, unemployment risk, and relative risk of unemployment at age 29 years among men for selected life course factors.

\begin{tabular}{|c|c|c|c|c|c|c|c|c|}
\hline \multirow[b]{2}{*}{ Category } & \multirow[b]{2}{*}{$\mathrm{N}$} & \multirow[b]{2}{*}{$\%$} & \multirow{2}{*}{$\begin{array}{c}\text { Not } \\
\text { employed }\end{array}$} & \multirow[b]{2}{*}{ Risk } & \multicolumn{2}{|c|}{ Crude } & \multicolumn{2}{|c|}{ Adjusted* } \\
\hline & & & & & Risk ratio & $(95 \% \mathrm{CI})$ & Risk ratio & $(95 \% \mathrm{CI})$ \\
\hline \multicolumn{9}{|l|}{ Model 1} \\
\hline \multicolumn{9}{|l|}{ Year of birth } \\
\hline 1967 & 31527 & 20.0 & 1449 & 0.046 & 1 & (Reference) & 1 & (Reference) \\
\hline 1968 & 32193 & 20.4 & 1467 & 0.046 & 0.99 & $(0.92-1.06)$ & 1.01 & $(0.94-1.08)$ \\
\hline 1969 & 32332 & 20.5 & 1424 & 0.044 & 0.96 & $(0.89-1.03)$ & 0.97 & $(0.90-1.04)$ \\
\hline 1970 & 30838 & 19.5 & 1429 & 0.046 & 1.01 & $(0.94-1.08)$ & 0.99 & $(0.93-1.07)$ \\
\hline 1971 & 31136 & 19.7 & 1486 & 0.048 & 1.04 & $(0.97-1.11)$ & 1.01 & $(0.94-1.08)$ \\
\hline \multicolumn{9}{|l|}{ Geographical region } \\
\hline Oslo & 9867 & 6.2 & 654 & 0.066 & 1 & (Reference) & 1 & (Reference) \\
\hline South-east & 53747 & 34.0 & 2525 & 0.047 & 0.71 & $(0.65-0.77)$ & 0.80 & $(0.73-0.87)$ \\
\hline South & 15409 & 9.8 & 778 & 0.050 & 0.76 & $(0.69-0.84)$ & 0.81 & $(0.73-0.90)$ \\
\hline West & 43067 & 27.3 & 1670 & 0.039 & 0.59 & $(0.54-0.64)$ & 0.70 & $(0.64-0.77)$ \\
\hline Trøndelag & 15061 & 9.5 & 630 & 0.042 & 0.63 & $(0.57-0.70)$ & 0.68 & $(0.61-0.75)$ \\
\hline North & 20563 & 13.0 & 943 & 0.046 & 0.69 & $(0.63-0.76)$ & 0.68 & $(0.62-0.75)$ \\
\hline Unknown & 312 & 0.2 & 55 & 0.176 & 2.66 & $(2.07-3.42)$ & 1.89 & $(1.46-2.45)$ \\
\hline \multicolumn{9}{|l|}{ Maternal age } \\
\hline$<20$ years & 11461 & 7.3 & 706 & 0.062 & 1.43 & $(1.31-1.57)$ & 1.33 & $(1.19-1.49)$ \\
\hline 20-29 years & 106849 & 67.6 & 4674 & 0.044 & 1.02 & $(0.95-1.09)$ & 1.14 & $(1.05-1.23)$ \\
\hline $30-34$ years & 23498 & 14.9 & 1010 & 0.043 & 1 & (Reference) & 1 & (Reference) \\
\hline 35-39 years & 11752 & 7.4 & 573 & 0.049 & 1.13 & $(1.03-1.25)$ & 0.96 & $(0.87-1.07)$ \\
\hline 40 years or more & 4466 & 2.8 & 292 & 0.065 & 1.52 & $(1.34-1.73)$ & 1.07 & $(0.93-1.23)$ \\
\hline \multicolumn{9}{|l|}{ Paternal age } \\
\hline$<20$ years & 1724 & 1.1 & 115 & 0.067 & 1.59 & $(1.32-1.91)$ & 1.23 & $(1.01-1.50)$ \\
\hline $20-29$ years & 85961 & 54.4 & 3656 & 0.043 & 1.01 & $(0.95-1.08)$ & 1.04 & $(0.97-1.11)$ \\
\hline $30-34$ years & 31616 & 20.0 & 1327 & 0.042 & 1 & (Reference) & 1 & (Reference) \\
\hline 35-39 years & 18390 & 11.6 & 875 & 0.048 & 1.13 & $(1.04-1.23)$ & 1.01 & $(0.93-1.11)$ \\
\hline 40 years or more & 14760 & 9.3 & 794 & 0.054 & 1.28 & $(1.18-1.40)$ & 0.91 & $(0.82-1.02)$ \\
\hline Unknown & 5575 & 3.5 & 488 & 0.088 & 2.09 & $(1.89-2.30)$ & 1.23 & $(0.99-1.53)$ \\
\hline Birth order & & & & & & & & \\
\hline First & 61390 & 38.8 & 2721 & 0.044 & 1 & (Reference) & 1 & (Reference) \\
\hline Second & 48448 & 30.7 & 2127 & 0.044 & 0.99 & $(0.94-1.05)$ & 1.13 & $(1.06-1.20)$ \\
\hline Third & 27736 & 17.6 & 1294 & 0.047 & 1.05 & $(0.99-1.12)$ & 1.19 & $(1.10-1.28)$ \\
\hline Fourth & 12367 & 7.8 & 627 & 0.051 & 1.14 & $(1.05-1.24)$ & 1.20 & $(1.09-1.32)$ \\
\hline Fifth or higher & 8085 & 5.1 & 486 & 0.060 & 1.36 & $(1.23-1.49)$ & 1.26 & $(1.12-1.41)$ \\
\hline Gestational age & & & & & & & & \\
\hline $17-32$ weeks & 1124 & 0.7 & 91 & 0.081 & 1.91 & $(1.57-2.33)$ & 0.91 & $(0.71-1.15)$ \\
\hline 33-36 weeks & 6320 & 4.0 & 345 & 0.055 & 1.29 & $(1.16-1.44)$ & 0.94 & $(0.83-1.05)$ \\
\hline 37-39 weeks & 49675 & 31.4 & 2372 & 0.048 & 1.13 & $(1.07-1.19)$ & 1.04 & $(0.99-1.10)$ \\
\hline 40-42 weeks & 88198 & 55.8 & 3735 & 0.042 & 1 & (Reference) & 1 & (Reference) \\
\hline 43-46 weeks & 6788 & 4.3 & 350 & 0.052 & 1.22 & $(1.09-1.35)$ & 1.10 & $(0.99-1.22)$ \\
\hline Missing values & 5921 & 3.7 & 362 & 0.061 & 1.44 & $(1.30-1.60)$ & 1.16 & $(1.05-1.29)$ \\
\hline Birthweight categories & & & & & & & & \\
\hline$\geq$ mean & 80090 & 50.7 & 3253 & 0.041 & 1 & (Reference) & 1 & (Reference) \\
\hline 0.01 to $1.00 \mathrm{SD}$ below mean & 55985 & 35.4 & 2616 & 0.047 & 1.15 & $(1.09-1.21)$ & 1.12 & $(1.06-1.17)$ \\
\hline 1.01 to $2.00 \mathrm{SD}$ below mean & 17440 & 11.0 & 1032 & 0.059 & 1.46 & $(1.36-1.56)$ & 1.30 & $(1.21-1.39)$ \\
\hline 2.01 to $3.00 \mathrm{SD}$ below mean & 3419 & 2.2 & 243 & 0.071 & 1.75 & $(1.54-1.98)$ & 1.47 & $(1.29-1.69)$ \\
\hline 3.01 to $4.00 \mathrm{SD}$ below mean & 892 & 0.6 & 78 & 0.113 & 2.15 & $(1.74-2.67)$ & 1.70 & $(1.35-2.14)$ \\
\hline$>4.00 \mathrm{SD}$ below mean & 200 & 0.1 & 33 & 0.165 & 4.06 & $(2.97-5.56)$ & 2.73 & $(1.94-3.85)$ \\
\hline Childhood disease & & & & & & & & \\
\hline Not stated & 154161 & 97.6 & 6486 & 0.042 & 1 & (Reference) & 1 & (Reference) \\
\hline Yes & 3865 & 2.4 & 769 & 0.199 & 4.73 & $(4.42-5.06)$ & 4.31 & $(4.02-4.62)$ \\
\hline Father's identity & & & & & & & & \\
\hline Known & 150855 & 95.5 & 6663 & 0.044 & 1 & (Reference) & 1 & (Reference) \\
\hline Unknown & 7171 & 4.5 & 592 & 0.083 & 1.87 & $(1.72-2.03)$ & 1.31 & $(1.08-1.60)$ \\
\hline Parental marital status & & & & & & & & \\
\hline Married & 124148 & 78.6 & 4657 & 0.038 & 1 & (Reference) & 1 & (Reference) \\
\hline Not married & 28990 & 18.4 & 2233 & 0.077 & 2.05 & $(1.96-2.16)$ & 1.47 & $(1.39-1.57)$ \\
\hline Unknown & 4888 & 3.1 & 365 & 0.075 & 1.99 & $(1.80-2.21)$ & 1.63 & $(1.47-1.81)$ \\
\hline Parents' number of children & & & & & & & & \\
\hline Equal & 132542 & 83.9 & 5325 & 0.040 & 1 & (Reference) & 1 & (Reference) \\
\hline Not equal & 18313 & 11.6 & 1338 & 0.073 & 1.82 & $(1.72-1.93)$ & 1.32 & $(1.24-1.40)$ \\
\hline Unknown & 7171 & 4.5 & 592 & 0.083 & 2.05 & $(1.89-2.23)$ & + & \\
\hline ontinues on next page & & & & & & & & \\
\hline
\end{tabular}




\begin{tabular}{|c|c|c|c|c|c|c|c|c|}
\hline \multicolumn{9}{|l|}{ Table 2 continued } \\
\hline \multicolumn{9}{|l|}{ Maternal income } \\
\hline High & 132122 & 83.6 & 5116 & 0.039 & 1 & (Reference) & 1 & (Reference) \\
\hline Low & 25904 & 16.4 & 2139 & 0.083 & 2.13 & $(2.03-2.24)$ & 1.64 & $(1.56-1.74)$ \\
\hline \multicolumn{9}{|l|}{ Maternal disability } \\
\hline No & 135345 & 85.6 & 5498 & 0.041 & 1 & (Reference) & 1 & (Reference) \\
\hline Yes & 22681 & 14.4 & 1757 & 0.077 & 1.91 & $(1.81-2.01)$ & 1.28 & $(1.21-1.36)$ \\
\hline \multicolumn{9}{|l|}{ Paternal income } \\
\hline High & 138602 & 87.7 & 5504 & 0.040 & 1 & (Reference) & 1 & (Reference) \\
\hline Low & 12253 & 7.8 & 1159 & 0.095 & 2.38 & $(2.24-2.53)$ & 1.44 & $(1.34-1.55)$ \\
\hline Unknown & 7171 & 4.5 & 592 & 0.083 & 2.08 & $(1.92-2.26)$ & $\dagger$ & \\
\hline \multicolumn{9}{|l|}{ Paternal disability } \\
\hline 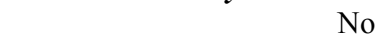 & 130699 & 82.7 & 5106 & 0.039 & 1 & (Reference) & 1 & (Reference) \\
\hline Yes & 20156 & 12.8 & 1557 & 0.077 & 1.98 & $(1.87-2.09)$ & 1.50 & $(1.41-1.60)$ \\
\hline Unknown & 7171 & 4.5 & 592 & 0.083 & 2.11 & $(1.95-2.29)$ & $\dagger$ & \\
\hline \multicolumn{9}{|l|}{ Model 2} \\
\hline \multicolumn{9}{|l|}{ Intellectual performance } \\
\hline 9 (high) & 5069 & 3.2 & 97 & 0.019 & 1 & (Reference) & 1 & (Reference) \\
\hline 8 & 10835 & 6.9 & 200 & 0.018 & 0.96 & $(0.76-1.23)$ & 0.97 & $(0.76-1.23)$ \\
\hline 7 & 18300 & 11.6 & 368 & 0.020 & 1.05 & $(0.84-1.31)$ & 1.04 & $(0.84-1.30)$ \\
\hline 6 & 27157 & 17.2 & 587 & 0.022 & 1.13 & $(0.91-1.40)$ & 1.10 & $(0.89-1.36)$ \\
\hline 5 & 31552 & 20.0 & 888 & 0.028 & 1.47 & $(1.20-1.81)$ & 1.39 & $(1.13-1.71)$ \\
\hline 4 & 26584 & 16.8 & 948 & 0.036 & 1.86 & $(1.52-2.29)$ & 1.70 & $(1.38-2.09)$ \\
\hline 3 & 15970 & 10.1 & 794 & 0.050 & 2.60 & $(2.11-3.20)$ & 2.25 & $(1.82-2.77)$ \\
\hline 2 & 8106 & 5.1 & 550 & 0.068 & 3.54 & $(2.86-4.39)$ & 2.89 & $(2.34-3.58)$ \\
\hline 1 (low) & 3445 & 2.2 & 516 & 0.150 & 7.83 & $(6.33-9.68)$ & 5.92 & $(4.78-7.33)$ \\
\hline No test & 7042 & 4.5 & 688 & 0.098 & 5.11 & $(4.14-6.30)$ & 3.96 & $(3.21-4.89)$ \\
\hline Did not meet at conscript & 3964 & 2.5 & 1619 & 0.408 & 21.34 & $(17.46-26.09)$ & 15.51 & $(12.65-19.01)$ \\
\hline \multicolumn{9}{|l|}{ BMI } \\
\hline$<18.50$ & 10210 & 6.5 & 550 & 0.054 & 1.65 & $(1.51-1.80)$ & 1.47 & $(1.35-1.60)$ \\
\hline $18.50-24.99$ & 122281 & 77.4 & 3998 & 0.033 & 1 & (Reference) & 1 & (Reference) \\
\hline 25.00-29.99 & 16684 & 10.6 & 624 & 0.037 & 1.14 & $(1.05-1.24)$ & 1.00 & $(0.92-1.09)$ \\
\hline 30.00 or more & 3365 & 2.1 & 205 & 0.061 & 1.86 & $(1.63-2.14)$ & 1.41 & $(1.23-1.61)$ \\
\hline Not measured & 1522 & 1.0 & 259 & 0.170 & 5.20 & $(4.64-5.84)$ & 3.52 & $(3.10-3.98)$ \\
\hline Did not meet at conscript & 3964 & 2.5 & 1619 & 0.408 & 12.49 & $(11.90-13.11)$ & $\dagger$ & \\
\hline \multicolumn{9}{|l|}{ Model 3} \\
\hline \multicolumn{9}{|l|}{ Educational attainment } \\
\hline Graduate tertiary & 13880 & 8.8 & 148 & 0.011 & 1 & (Reference) & 1 & (Reference) \\
\hline Undergraduate tertiary & 34078 & 21.6 & 521 & 0.015 & 1.43 & $(1.20-1.72)$ & 1.51 & $(1.26-1.82)$ \\
\hline Final upper secondary & 64882 & 41.1 & 1286 & 0.020 & 1.86 & $(1.57-2.20)$ & 1.92 & $(1.61-2.29)$ \\
\hline Basic upper secondary & 32924 & 20.8 & 3322 & 0.101 & 9.46 & $(8.04-11.14)$ & 7.14 & $(5.99-8.50)$ \\
\hline Lower secondary or less & 11412 & 7.2 & 1526 & 0.134 & 12.54 & $(10.61-14.82)$ & 8.65 & $(7.24-10.35)$ \\
\hline Unknown & 850 & 0.5 & 452 & 0.532 & 49.87 & $(41.98-59.24)$ & 12.30 & $(10.21-14.82)$ \\
\hline \multicolumn{9}{|l|}{ Model 4} \\
\hline \multicolumn{9}{|l|}{ Marital status at age 28} \\
\hline Married & 33864 & 21.4 & 551 & 0.016 & 1 & (Reference) & 1 & (Reference) \\
\hline Unmarried & 121143 & 76.7 & 6498 & 0.054 & 3.29 & $(3.02-3.59)$ & 2.31 & $(2.12-2.51)$ \\
\hline Previously married & 3010 & 1.9 & 205 & 0.068 & 4.19 & $(3.58-4.89)$ & 2.53 & $(2.17-2.93)$ \\
\hline Unknown & 9 & 0.0 & 1 & 0.111 & 6.83 & $(1.07-43.42)$ & 5.92 & $(1.18-29.71)$ \\
\hline
\end{tabular}

* Adjusted for other variables in the model, and variables in preceding models

$\uparrow$ Category dropped due to collinearity

shows that low education level, adjusted for all variables in preceding models, was strongly associated with unemployment. The gradient in unemployment risk ranged from 0.011 (graduate tertiary level) to 0.134 (lower secondary level or less). The unemployment risk was also quite low among married men (model 4). The adjusted RRs in the unmarried and previously married category were accordingly strong.

PAR estimates for variables included in the four models are presented in table 3 . The adjusted PARs in model 1 show that most of the nine early determinants had moderate impact on the unemployment level, with low maternal income, maternal marital status, childhood disease, birthweight, and paternal disability as the most influential.

Model 2 results show that intellectual performance attributed strongly to the unemployment risk (table 3 ). BMI had a moderate impact. The early determinant PARs were considerably reduced when intellectual performance and own education level were included 
Table 3. Population risks of unemployment at age 29 attributed to selected life course factors.

\begin{tabular}{lccccccccc}
\hline & Persons & \multicolumn{3}{c}{ Model 1 } & \multicolumn{3}{c}{ Model 2 } & \multicolumn{3}{c}{ Model 3 } & \multicolumn{2}{c}{ Model 4 } \\
\cline { 3 - 10 } Category & excluded & PAR* & $(95 \%$ CI $)$ & PAR* & $(95 \%$ CI $)$ & PAR* & $(95 \%$ CI $)$ & PAR* & $(95 \%$ CI $)$ \\
\hline Birthweight below mean & 0 & $8 \%$ & $(6-10)$ & $3 \%$ & $(1-5)$ & $2 \%$ & $(0-4)$ & $1 \%$ & $(0-3)$ \\
Childhood disease & 0 & $8 \%$ & $(8-9)$ & $4 \%$ & $(4-4)$ & $3 \%$ & $(3-3)$ & $3 \%$ & $(3-3)$ \\
Father's identity unknown & 0 & $2 \%$ & $(1-3)$ & $1 \%$ & $(0-2)$ & $1 \%$ & $(0-2)$ & $1 \%$ & $(0-2)$ \\
Parents not married & 4888 & $10 \%$ & $(9-12)$ & $9 \%$ & $(8-10)$ & $6 \%$ & $(5-8)$ & $6 \%$ & $(5-7)$ \\
Unequal number of children & 7121 & $5 \%$ & $(4-6)$ & $4 \%$ & $(3-5)$ & $3 \%$ & $(2-3)$ & $2 \%$ & $(2-3)$ \\
Low maternal income & 0 & $12 \%$ & $(10-13)$ & $8 \%$ & $(7-9)$ & $6 \%$ & $(5-7)$ & $6 \%$ & $(5-7)$ \\
Maternal disability & 0 & $5 \%$ & $(4-6)$ & $3 \%$ & $(2-4)$ & $2 \%$ & $(1-3)$ & $2 \%$ & $(1-3)$ \\
Low paternal income & 7121 & $5 \%$ & $(4-6)$ & $4 \%$ & $(3-5)$ & $3 \%$ & $(3-4)$ & $3 \%$ & $(3-4)$ \\
Paternal disability & 7121 & $8 \%$ & $(7-9)$ & $5 \%$ & $(4-6)$ & $4 \%$ & $(3-4)$ & $3 \%$ & $(3-4)$ \\
Intellectual performance & 11006 & & & $37 \%$ & $(30-44)$ & $-15 \%$ & $(-25$ to -4$)$ & $-17 \%$ & $(-27$ to -6) \\
BMI & 5486 & & & $4 \%$ & $(3-6)$ & $3 \%$ & $(1-4)$ & $2 \%$ & $(1-4)$ \\
Educational attainment & 850 & & & & & $60 \%$ & $(53-65)$ & $60 \%$ & $(53-65)$ \\
Marital status at age 28 & 9 & & & & & & & $53 \%$ & $(49-56)$ \\
Total & & $46 \%$ & $(44-47)$ & $61 \%$ & $(56-65)$ & $81 \%$ & $(77-85)$ & $91 \%$ & $(89-93)$ \\
\hline
\end{tabular}

* Adjusted for year of birth, geographical region, maternal and paternal age, birth order, gestational age and other variables included in the models

Table 4. Distribution, unemployment risk, and unemployment risk differences in association with combined categories of birthweight, disadvantage in parental factors, and childhood disease.

\begin{tabular}{|c|c|c|c|c|c|c|c|c|c|c|}
\hline \multicolumn{3}{|c|}{ Category combination* } & \multirow[b]{2}{*}{ Number } & \multirow[b]{2}{*}{$(\%)$} & \multirow[b]{2}{*}{$\begin{array}{c}\text { Not } \\
\text { employed }\end{array}$} & \multirow[b]{2}{*}{ Risk } & \multicolumn{2}{|c|}{ Crude } & \multicolumn{2}{|c|}{ Adjusted $\dagger$} \\
\hline $\begin{array}{l}\text { Birth- } \\
\text { weight }\end{array}$ & $\begin{array}{c}\text { Parental } \\
\text { factors }\end{array}$ & $\begin{array}{c}\text { Childhood } \\
\text { disease }\end{array}$ & & & & & Risk dif & ence $(95 \% \mathrm{CI})$ & Risk dif & ence $(95 \% \mathrm{CI})$ \\
\hline 0 & 0 & 0 & 41448 & $(26.2)$ & 984 & 0.024 & 0 & (Reference) & 0 & (Reference) \\
\hline 1 & 0 & 0 & 37647 & $(23.8)$ & 971 & 0.026 & 0.002 & $(0.000-0.004)$ & 0.002 & $(0.000-0.003)$ \\
\hline 0 & 1 & 0 & 36840 & $(23.3)$ & 2004 & 0.054 & 0.031 & $(0.027-0.035)$ & 0.028 & $(0.024-0.032)$ \\
\hline 0 & 0 & 1 & 895 & $(0.6)$ & 93 & 0.104 & 0.080 & $(0.061-0.103)$ & 0.078 & $(0.059-0.101)$ \\
\hline 1 & 1 & 0 & 38226 & $(24.2)$ & 2527 & 0.066 & 0.042 & $(0.038-0.047)$ & 0.038 & $(0.033-0.043)$ \\
\hline 1 & 0 & 1 & 981 & $(0.6)$ & 177 & 0.180 & 0.157 & $(0.132-0.185)$ & 0.149 & $(0.125-0.177)$ \\
\hline 0 & 1 & 1 & 907 & $(0.6)$ & 172 & 0.190 & 0.166 & $(0.140-0.196)$ & 0.151 & $(0.127-0.179)$ \\
\hline 1 & 1 & 1 & 1082 & $(0.7)$ & 327 & 0.302 & 0.278 & $(0.247-0.313)$ & 0.250 & $(0.220-0.282)$ \\
\hline
\end{tabular}

* Category 0 : birthweight $\geq$ mean, no disadvantage in parental factors, no childhood disease; category 1 : birthweight $<$ mean, disadvantage(s) in parental factors, childhood disease

$\dagger$ Adjusted for year of birth, geographical region, maternal and paternal age, birth order, and gestational age

(models 2 and 3). Education level had in itself major impact (PAR 60\%). The intellectual performance PAR estimate was negative in model 3: a closer examination showed that the lowest unemployment levels for the large upper secondary level groups were not experienced for subjects with top intellectual test result (the reference category), but for those who scored 5 to 7 . Model 4 shows that own marital status, next to educational attainment, was the most influential factor with a PAR of $53 \%$. Marital status had little additional role as a mediator of the early determinant effects.

In the interaction analysis, we examined the effect of combined low birthweight and childhood disease, adjusted for the other model 1 variables. The adjusted unemployment risk for both factors was $0.078(0.055$ to 0.101 ) in excess of additivity. The corresponding departure from additivity by the combination of low birthweight and disadvantage in parental factors was only 0.008 (0.004 to 0.012$)$, whereas combined childhood disease and disadvantage in parental factors was associated with a risk in excess of additivity of 0.056 (0.034 to 0.078$)$. Distributions, risks, and crude and adjusted risk differences of all combinations of the three factors are given in table 4 . The adjusted risk differences in table 4 confirm that the childhood disease unemployment risk in combination with one or both other factors was considerably in excess of additivity whereas the combined low birthweight-parental factor disadvantage category had a risk close to additivity.

\section{DiscUSSION}

The present study provides additional knowledge of the relation between early life health and social condi- 
tions, and the start of working life for young men. We find documentation that differentials in work participation among young men actually is rooted in childhood.

The impact of birthweight on unemployment risk was largely mediated through intellectual performance, judged by the change in PAR estimates when performance results were added. However, this estimation had low power because men lacking conscript performance results were likely to be of low birthweight and unemployed. The finding is in agreement with our hypothesis and other studies addressing the relation between birthweight, cognitive function, and educational achievements or adult social functions $(2,3,8,15-17)$.

We found that several parental factors, mutually adjusted for in the modelling, were associated with subsequent unemployment. These parental factors taken together were the main contributors to the $46 \%$ PAR of all determinants in model 1. This supports the interpretation that the cumulative burden of social and material disadvantage in childhood and adolescence influences adult age social function. The modest protective unemployment effect of paternal (but not maternal) death could be fortuitous, but we might speculate that it could be interpreted as a consequence of early role modelling: boys whose father was deceased could adapt a family supporter role. This role model theory would be in line with disability pension risk results in this population: the hazard of own disablement pension was higher when the parent of one's own gender was disabled compared with having a disabled parent of opposite gender (30). Further, the results suggest additional contribution to the unemployment risk from factors relating to intellectual performance in young adult age, educational attainment, and marital status. This is in support of an accumulative influence of factors in the whole life course (23).

The results of the interaction analysis suggest that the effect of childhood disease on subsequent unemployment risk is considerably increased if there are additional early determinants at work as well. This means that the small proportion of young men with congenital malformations, or disablement or chronic disease from childhood, are vulnerable to the additional effect of low birthweight or early social disadvantage.

The main strengths of our study are complete follow-up, large size, and availability of prospectively collected data from several national registers throughout the life course. However, several limitations are also apparent.

First, there are problems of interpretation. We applied complex analytical models in a non-randomised study using data inevitably hampered with error. The safest way to avoid misinterpretations would have been to use a stratified approach. This was not done to disentangle the separate effects of the seven parental factors. We may safely conclude that parental factors related to economy, health, and family structure had influence, and these factors taken together had larger impact than birthweight and childhood disease. Apart from this, we should be cautious in interpreting the separate role of these parental factors. The same interpretation problem could easily arise if interaction was not considered when interpreting the PAR results of intellectual performance on unemployment risk after taking educational attainment into account.

A second limitation is that our models are unlikely to be truly representative of the intricate pathways from determinants along the life-course $(23,26,27)$. We anticipated that the nine early determinants in model 1 were hierarchically on the same level by considering these mutually adjusted estimates as unbiased. This is probably not correct. We could also question the correct direction of the relation between all variables in the models. One example: men who were previously married at age 28 might be in this position because they lost their work earlier, and did not regain work until age 29. Thus, marital status could be a consequence and not a cause of work participation, and it could be erroneous to consider marital status as a predictor of work participation.

A third problem is that the outcome under study is probably not restricted to unemployment. One third of those who met the unemployment criterion were disability pensioners. The category could also include young people financially supported by parents or spouse, men with accumulated wealth, and men with income not reported to the income register. The net effect on the associations studied of this outcome characterisation problem is not straightforward, as they supposedly will have different directions.

Finally, we might have a problem when disregarding subjects who died or emigrated in the calendar year of their 29th birthday. This is a minor problem, and Cox regression analysis where censoring was considered produced hazard ratios slightly in excess of the RRs reported. However, we abandoned this solution because PAR estimation was not a comprehensible option.

This study provides evidence supporting the hypothesis that work participation in young adult age is influenced by early life experiences, as well as circumstances acting during the life course. This should have implications for directions of research as well as prevention.

\section{ACKNOWLEDGEMENTS}

This work was supported by the Research Council of Norway. We thank Ole-Henrik Edland at the Medical Birth Registry of Norway and Tove Bergseteren at Statistics Norway for file preparations, Ola Thune at the National Insurance Administration for file preparations and linking, and KarlChristian Nordby at the National Institute of Occupational Health for developing the Hosmer-Lemeshow spreadsheet for estimating confidence limits of interaction measures. 


\section{REFERENCES}

1. Kristensen P, Bjerkedal T, Irgens LM. Birthweight and work participation in adulthood. Int J Epidemiol 2004; 33: 849-56.

2. Richards M, Hardy R, Kuh D, Wadsworth MEJ. Birthweight, postnatal growth and cognitive function in a national UK birth cohort. Int J Epidemiol 2002; 31: 342-8.

3. Jefferis BJMH, Power C, Hertzman C. Birth weight, childhood socioeconomic environment, and cognitive development in the 1958 British birth cohort study. BMJ 2002; 325: 305-8.

4. Martyn CN, Gale CR, Sayer AA, Fall C. Growth in utero and cognitive function in adult life: follow up study of people born between 1920 and 1943. BMJ 1996; 312: 1393-97.

5. Toft Sørensen H, Sabroe S, Olsen J, Rothman KJ, Gillman MW, Fischer P. Birth weight and cognitive function in young adult life: historical cohort study. BMJ 1997; 315: 401-03.

6. Seidman DS, Laor A, Gale R, Stevenson DK, Mashiach S, Danon YL. Birth weight and intellectual performance in late adolescence. Obstet Gynecol 1992; 79: 543-46.

7. Lundgren EM, Cnattingius S, Jonsson B, Tuvemo T. Birth characteristics and different dimensions of intellectual performance in young males: a nationwide population-based study. Acta Paediatr 2003; 92: 1138-43.

8. Ericson A, Källén B. Very low birthweight boys at the age of 19. Arch Dis Child Fetal Neonatal Ed 1998; 78: F171-F174.

9. Shenkin SD, Starr JM, Deary IJ. Birth weight and cognitive ability in childhood: a systematic review. Psychol Bull 2004; 130: 989-1013.

10. Shenkin SD, Starr JM, Pattie A, Rush MA, Deary IJ. Birth weight and cognitive function at age 11 years: the Scottish Mental Survey 1932. Arch Dis Child 2001; 85: 189-97.

11. Lawlor DA, Bor W, O'Callaghan MJ, Williams GM, Najman JM. Intrauterine growth and intelligence within sibling pairs: findings from the Mater-University study of pregnancy and its outcomes. J Epidemiol Community Health 2004; 59: 279-82.

12. Matte TD, Bresnahan M, Begg MD, Susser E. Influence of variation in birth weight within normal range and within sibships on IQ at age 7 years: cohort study. BMJ 2001; 323: 310-4.

13. Osler M, Andersen A-M N, Due P, Lund R, Damsgaard MT, Holstein BE. Socioeconomic position in early life, birth weight, childhood cognitive function, and adult mortality. A longitudinal study of Danish men born in 1953. J Epidemiol Community Health 2003; 57: 681-6.

14. Record RG, McKeown T, Edwards JH. The relation of measured intelligence to birth weight and duration of gestation. Ann Hum Genet 1969; 33: 71-9.

15. Weindrich D, Jennen-Steinmetz C, Laucht M, Schmidt MH. Late sequelae of low birthweight: mediators of poor school performance at 11 years. Dev Med Child Neurol 2003; 45: 463-9.

16. Hansen BM, Dinesen J, Hoff B, Greisen G. Intelligence in preterm children at four years of age as a predictor of school function: a longitudinal controlled study. Dev Med Child Neurol 2002; 44: 517-21.

17. Kuh D, Richards M, Hardy R, Butterworth S, Wadsworth MEJ. Childhood cognitive ability and deaths up until middle age: a post-war birth cohort study. Int J Epidemiol 2004; 33: 408-13.

18. Irgens LM. The Medical Birth Registry of Norway. Epidemiological research and surveillance throughout 30 years. Acta Obstet Gynecol Scand 2000; 79: 435-9.

19. Medical Birth Registry of Norway. Births in Norway through 30 years. Bergen: Medical Birth Registry of Norway, 1997.

20. Sundet JM, Barlaug DG, Torjussen TM. The end of the Flynn effect? A study of secular trends in the mean intelligence test scores of Norwegian conscripts during half a century. Intelligence 2004; 32: 349-62.

21. Statistics Norway. Norwegian standard classification of education. Revised 2000. Oslo-Kongsvinger: Statistics Norway, 2003.

22. Greenland S. Model-based estimation of relative risks and other epidemiologic measures in studies of common outcomes and in case-control studies. Am J Epidemiol 2004; 160: 301-5.

23. Ben-Shlomo Y, Kuh D. A life course approach to chronic disease epidemiology: conceptual models, empirical challenges and interdisciplinary perspectives. Int J Epidemiol 2002; 31: 285-93.

24. Victora CG, Huttly SR, Fuchs SC, Olinto MTA. The role of conceptual frameworks in epidemiological analysis: a hierarchical approach. Int J Epidemiol 1997; 26: 224-7.

25. Lamont D, Parker L, White M, Unwin N, Bennett SMA, Cohen M, Richardson D, Dickinson HO, Adamson A, Alberti KGMM, Craft AW. Risk of cardiovascular disease measured by carotid intima-media thickness at age 49-51: lifecourse study. BMJ 2000; 320: 273-8.

26. Weitkunat R, Wildner M. Exploratory causal modeling in epidemiology: are all factors created equal? $J$ Clin Epidemiol 2002; 55: 436-44.

27. Greenland S, Pearl J, Robins JM. Causal diagrams for epidemiologic research. Epidemiology 1999; 10: 37-48. 
28. Greenland S. Application of stratified analysis methods. In: Rothman KJ, Greenland S, editors. Modern epidemiology. $2^{\text {nd }}$ Edition. Philadelphia: Lippincott-Raven, 1997: 281-300.

29. Hosmer DW, Lemeshow S. Confidence interval estimation of interaction. Epidemiology 1992; 3: 452-6.

30. Kristensen P, Bjerkedal T, Brevik JI. Long term effects of parental disability: a register based life course follow-up of Norwegians born in 1967-1976. Nor J Epidemiol 2004: 14: 97-105. 